\title{
Alzheimer's disease: genetic variables and risk
}

$\mathrm{T}$ he risk of Alzheimer's disease may come down to the expression of various forms of the human apolipoprotein E gene $(a p o E)$. Jean-Cosme Dodart and colleagues ${ }^{1}$ have recently shown that injecting a variant of $a p o E$ into the brains of mice has an effect on the formation of the amyloid plaques characteristic of Alzheimer's disease. Their research contributes more evidence that $a p o E$ is a major risk factor for Alzheimer's disease and points to gene delivery as a potential treatment for the most common form of dementia among elderly people worldwide.

\section{Genetic risk factors}

Two hallmarks characterize Alzheimer's disease: plaques and tangles. The plaques are chains of amino acids that are pieces of the amyloid precursor protein, whereas the tangles are aggregates of the protein tau. It appears that the amyloid plaques are precursors to the formation of tangles; ${ }^{2}$ whether or not this is the case, it is clear that these 2 abnormalities ultimately lead to loss of cognitive function.

Significant effort has gone into attempting to understand the genetic factors that play a role in the formation of plaques and tangles. Although 3 genes have been identified and linked to early-onset Alzheimer's disease, only apoE has been shown to be consistently linked to the more common late-onset form of the disease.

The human apoE gene has 3 versions (apoE- $\varepsilon 2,-\varepsilon 3,-\varepsilon 4)$, each of which encodes a protein involved in the transport of triglycerides and cholesterol. Interestingly, apoE- $\varepsilon 4$ was shown to be associated with an increased risk of Alzheimer's disease in Caucasians homozygous for $a p o E-\varepsilon 4$ (odds ratio [OR] $14.9,95 \%$ confidence interval [CI] 10.8-20.6). Conversely, in the same study, apoE- $\varepsilon 2$ appeared to decrease this risk (OR
$0.6,95 \%$ CI $0.2-2.0$ for $\varepsilon 2 / \varepsilon 2$ and OR $0.6,95 \%$ CI $0.5-0.8$ ع2/ع3). ${ }^{3}$ In 2000, Holtzman and colleagues found that $a p o E-\varepsilon 4$ promotes the laying down of amyloid plaques in mice, which further highlights the importance of this genetic factor. ${ }^{4}$ However, how the ApoE protein contributes to the pathology of Alzheimer's disease was still not clear, and direct in-vivo demonstration that versions of ApoE affect plaque formation was lacking. ${ }^{1}$

\section{Delivering apoE to the brain}

Dodart and colleagues took an elegant approach to investigating these questions by injecting viruses capable of expressing one of the subtypes of $a p o E$ into the brains of a mouse model of Alzheimer's that formed amyloid plaques but lacked apoE. Five weeks later, the researchers were able to detect the presence of ApoE protein, which appeared to be expressed largely in neurons.

The ability to directly inject $a p o E$ into the brains of mice gave Dodart and colleagues the chance to discern the effects of its variants, in particular $a p o E-\varepsilon 4$ and $a p o E-\varepsilon 2$. After 5 weeks, the mice given apoE- $\varepsilon 4$ had a two- to threefold increase in amyloid peptides in the hippocampus, which also appeared to cover a larger area of the brain. Two findings that suggest that $a p o E-$ $\varepsilon 4$, in the absence of ApoE, directly promotes the formation of amyloid plaques. In contrast, $a p o E-\varepsilon 2$ injection reduced the levels of amyloid peptides by $30 \%$ to $50 \%$, which reveals a protective role for this protein. This protection could occur even in the presence of the regular ApoE protein.

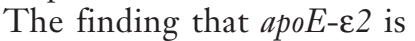
protective even in the presence of other apoE genes is perhaps significant in light of existing epidemiologic data, which suggest that this version of $a p o E$ decreases

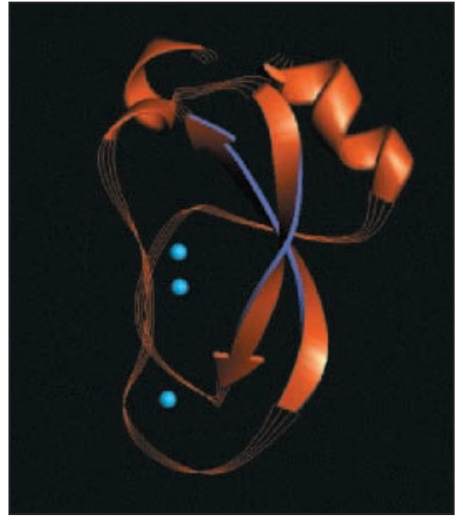

Protein molecule: Alzheimer amyloid B. Reprinted, with permission, from the European Bioinformatics Institute.

the risk of Alzheimer's disease in the human population. ${ }^{5}$ Although it is still too early to tell, this finding, as the authors point out, suggests that the expression of $a p o E$ $\varepsilon 2$ in susceptible areas of the brain (perhaps through a similar viral vector) could constitute a treatment for Alzheimer's disease. Regardless of whether this ever comes to be, Dodart and colleagues' work highlights apoE$\varepsilon 2$ as an interesting target for study. - David Secko, Vancouver

\section{References}

1. Dodart JC, Marr RA, Koistinaho M, Gregersen BM, Malkani S, Verma IM, et al. Gene delivery of human apolipoprotein $\mathrm{E}$ alters brain $\mathrm{A}\{$ beta\} burden in a mouse model of Alzheimer's disease. Proc Natl Acad Sci U S A 2005;102(4): 1211-6.

2. Lewis J, Dickson DW, Lin WL, Chisholm L, Corral A, Jones G, et al. Enhanced neurofibrillary degeneration in transgenic mice expressing mutant tau and APP. Science 2001;293 (5534):1487-91

3. Farrer LA, Cupples LA, Haines JL, Hyman B, Kukull WA, Mayeux R, et al. Effects of age, sex, and ethnicity on the association between apolipoprotein $\mathrm{E}$ genotype and Alzheimer disease. A meta-analysis. APOE and Alzheimer Disease Meta Analysis Consortium. 7AMA 1997;278(16):1349-56.

4. Holtzman DM, Bales KR, Tenkova T, Fagan AM, Parsadanian M, Sartorius $\mathrm{LJ}$, et al. Apolipoprotein E isoformdependent amyloid deposition and neuritic degeneration in a mouse model of Alzheimer's disease. Proc Natl Acad Sci U S A 2000;97(6):2892-7.

5. Bertram L, Tanzi RE. Alzheimer's disease: one disorder, too many genes? [review] Hum Mol Genet 2004; 13 Spec No 1:R135-41. Epub 2004 Feb 05. 